\title{
The Impact of the Feminist Heroine: Elizabeth in Pride and Prejudice
}

\author{
Hui-Chun CHANG \\ School of Humanities, Tsinghua University \\ Beijing, P.R. China 100084 \\ E-mail: kristsinghua@gmail.com
}

Received: 25-12-2013

doi:10.7575/aiac.ijalel.v.3n.3p.76
Accepted: 27-01-2014

Published: 01-05-2014

\begin{abstract}
This paper critically examines the feminist significance of Elizabeth Bennet, heroine of Jane Austen's Pride and Prejudice. The feminist view found in Pride and Prejudice is well-supported in literary criticism yet little discussion has focused on Elizabeth's feminism as seen in the prominent contrast to her female foils within the novel, namely Caroline, Jane, and Charlotte. Each of these women conforms to the socially imposed gender norms of Regency England, while Elizabeth artfully challenges gender inequality. As other women adapt their views to increase their chances of marriage, Elizabeth persistently refuses to capitulate. Defying traditional gender norms, Elizabeth affirms her feminist perspective by helping to shape Mr. Darcy's moral character to match her own. Elizabeth inspires Mr. Darcy to set aside the pride he has in his high station in society in order to win her affections and take her hand in marriage. I argue that Elizabeth's character is not feminist in isolation, but is understood only in contrast to Caroline, Jane, and Charlotte. This claim is supported by an in-depth comparison of Elizabeth and each of the female foils.
\end{abstract}

Keywords: feminism, Elizabeth Bennet, moral character, gender inequality, foil contrast

\section{Introduction}

This study posits that the unconventional position of the main character Elizabeth has a corrective purpose, shown through her impact on Mr. Darcy's moral character in Pride and Prejudice. Elizabeth's ability to exert positive influence over one of society's most affluent men, Mr. Darcy, offers evidence for a feminist ability to subvert the male-dominated society of Regency England. A close examination of Elizabeth in contrast to three other female characters from the novel reveals the feminist objective found within her beliefs. This study maintains that Elizabeth's feminist perspective is not feminism in the extreme sense, but rather demonstrates her determination to assert independence from societal bounds and influence traditional views about marriage that hindered women's self-autonomy at the time in Regency England. To stress the purpose of Elizabeth's feminism, her unconventional ambition of seeking gender equality is made more salient with the presence of three other comparable female characters in the novel. Caroline, Jane and Charlotte are foils representing women of the time who believe they must alter their views in order to gratify the men in their lives and attain a husband. Elizabeth acts contrary to her female foils, holding steadfast to her feminist intent throughout the novel. Elizabeth's feminism displayed in contrast with Caroline, Jane and Charlotte's traditional Regency England female personas reveals the purpose of her unconventionality for impacting Mr. Darcy, intended by Austen.

\subsection{Research Structure and Hypothesis}

This paper will begin with a summary of early feminist theories, followed by an analysis of Elizabeth's feminist influence through a foil contrast of the other three traditional female characters. Caroline, Jane, and Charlotte are three examples of foil contrast that reveal how Elizabeth maintains her independence from masculine influences which dominate society. Elizabeth's independence is illustrated in her refusal to bend to the will of a male-dominated society and her rejection of social dictates. I argue that Elizabeth, the female protagonist, transcends her expected role, exerting influence over her male love interest, Mr. Darcy. Elizabeth's feminist views impact Mr. Darcy's moral character, adjusting his prideful nature and extending his worldview to match her own moral standards for a husband.

Pride and Prejudice, ${ }^{\mathrm{i}}$ written by Jane Austen in 1813, is a renowned novel set in the world of Regency England and centers on the fortunes of the five daughters of the Bennet family. As there are no sons in the family, the inheritance must go to the next male heir, their cousin Mr. Collins. To ensure the Bennet family's future financial security, Mrs. Bennet strives to see her daughters married. Elizabeth, the second-eldest daughter, takes the role of heroine in the novel. She will not bend to her mother's will and accept a marriage proposal from Mr. Collins due to his conceited nature. Elizabeth's rejection of societal conventions illustrates her feminism. The significance of Elizabeth's character as a feminist was at times overlooked, thus this paper aims to establish Elizabeth's feminist role is not merely "parodic in structure and theme" (Brown, 1969: 1582). The feminist views manifest through the protagonist Elizabeth have a purpose other than comedic effect. Through Elizabeth, Austen provides clues to her dissatisfaction with the limitations imposed by society. This paper challenges the one-dimensional view that the protagonist's feminist attitude was purely intended by Austen for comedy. I argue that Elizabeth's feminist intent serves the purpose of impacting Mr. Darcy's 
character. By using the foil contrast method, I believe that this paper provides a more comprehensive view of Elizabeth's feminist intent.

\section{Relevant Literature}

Austen has been described within literature as a feminist; however this is a contested claim. The only consensus among literary critics is that she had a critical view of the world. Among her works, Pride and Prejudice is more often cited by scholars as having a feminist perspective, and the feminist overtones are prevalent in Austen's heroine, Elizabeth (Monteiro, 2008: 109). This paper takes research on Elizabeth's feminism one step further by providing evidence from foil contrasts between Elizabeth and three other female characters from the novel for analyzing her impact on Mr. Darcy. The purpose of Elizabeth's feminist views is better displayed through the foil comparisons with Caroline, Jane and Charlotte. It is essential to grasp the underlying rationale of early feminist theories two centuries ago in order to address Austen's view properly. Feminism seen in Austen's early 19th Century writing was in a preliminary stage. Austen is aware of social differences between genders, displayed, for example, in her critical view towards the lack of education for women. In Pride and Prejudice, Austen asserts her awareness of differing views on what constitutes necessary education for women through a discourse between several characters at Netherfield (Brown, 1978: 328). Austen displays her view of women's suffrage through Elizabeth, a woman who for the time was uncommonly accomplished in reading. Austen also constructs a male protagonist, Mr. Darcy, who perceives reading to be a necessary accomplishment for women and deems Elizabeth's intellect an admirable quality.

Austen uses the novel to critique the economic and social privileges afforded to men and denied to women (Hall, 2009: 1-2). It is clear from the start of Pride and Prejudice that Austen is mindful of the reality of societal conditions under which her characters live, in particular the differences in the autonomy that economic independence grants to men and the dependency that is expected of women (Bochman, 2005: 96). The male characters in Pride and Prejudice are not omnipotent simply by virtue of their superior economic and social statuses. Instead the men within Pride and Prejudice are often portrayed as bumbling, as in the case of Sir William Lucas; silly, such as Mr. Collins; or dependent on the opinions of others to form judgments, as is Mr. Bingley (Newton, 1978: 32).

Elizabeth's criticism and mockery of men in the novel express her views on a patriarchal society, explicated by Marxist Feminist theory. The concept of Marxist Feminism, discussed by Donovan (1991), is based on a patriarchal view of the world. The Marxist Feminist argues that dismantling capitalism, customarily governed by a patriarchal society, provides a way to free women (Hennessy \& Ingraham, 1997: 3). Marxist Feminism recognizes that constructions of gender are male-centered according to the acceptable view of men at the time. This theory also suggests that one's understanding of reality should be based on an impartial view of the world. Jameson's theory of Marxist historicism further clarifies this concept. He suggests that if one were to consider the effect that history, politics, and the dictates of society have had on the development of a piece of literature, one would come to a whole new understanding (in Sullivan, 1991 571). For example, Newman notes that a close examination of Pride and Prejudice shows women are at the mercy of "the male control of the means of production" (1983: 699). However, if one applies Jameson's logic, the heroine, Elizabeth, fights against this patriarchal society and is successful in persuading Mr. Darcy, a powerful male figure, to alter his worldview (Sullivan, 1991: 571). Elizabeth's ability to impact Mr. Darcy's perceptions is the reason Pride and Prejudice is often proclaimed by scholars to be a feminist text (Bochman, 2005: 88).

Although Austen's criticism of society still follows in a feminist literary tradition, her character portrayal illustrates an adept ingenuity in writing. Feminism in the early 19th Century was still in its infancy. Toolan remarks that few examples of "agentive" females appear in literature until the approach of the 20th Century (1988: 246). In the 19th Century, most female heroines found in literature are not in charge of their own fate, especially to the extent that Austen affords her female protagonist. Women were subservient to men in many ways, having nearly no property rights, legal rights, or control over their own destinies. Writers were commonly bound by strict patriarchal views of society. Writing about female protagonists who not only had a role in their own destiny, but also impacted the lives of others was outside of the imaginative scope of most authors. Austen pushed past the bounds of her own creativity and challenged societal confines to provide enduring heroines with the capability to defy social constraints and control their own fates. Austen was ahead of her time, portraying a female protagonist able to affect her own situation.

Elizabeth's feminist qualities find resonance with Duckworth's (1991) review of various studies of Jane Austen's literary works. He concludes that her feminism "was not as radical as sometimes proclaimed" (88). Because Austen was aware of the constraints of her time, Duckworth argues that it was only possible to help the feminist cause in a piecemeal way (1991). While questioning certain aspects of patriarchal society, such as submission of women to a higher male authority, Austen especially criticizes the social convention of securing a good marriage on economic grounds in Pride and Prejudice. Duckworth argues that feminism does not require fundamental change as long as there is progress towards elevating the position of women within the society. Elizabeth, with respect to her defiant nature in opposition to the expectations of proper feminine behavior, shows a true feminist viewpoint. Newton (1978) suggests that the characterization of Elizabeth as judgmental and challenging provided Austen with an outlet for critical energies that she could not otherwise share with the world. Elizabeth, through her rejection of traditional Regency female behavior, such as her enjoyment of exercise (Johnson, 1989), portrays a want for the autonomy that was unavailable to women of the time (Newton, 1978). Furthermore, Austen's depiction of Elizabeth's character is distinct from many writers of the time who allowed women "sensibility, depths of feeling and understanding, but....rarely conceded power or independence" (Toolan, 1988: 245). Austen is able to comment on the social constraints surrounding her own life by allowing Elizabeth to defy them. Elizabeth not only expresses opinions but her views lead to real change in Mr. Darcy's 
moral character by the end of the story.

\section{Textual Analysis}

To illustrate the feminist standpoint of Elizabeth's character in the novel, the discussion will shift to an analysis of foil contrasts. Elizabeth's manifest feminism will be made evident in opposition to her peers. Elizabeth speaks her own mind decidedly, unwilling to bend to the rules of societal dictate. Caroline, Jane and Charlotte portray conventional women of Regency England, respectful of social hierarchy. These women are chosen as foils because they provide prime examples of divergent characters. They represent stereotypes of traditional women of marriageable age who modify themselves in the pursuit of a husband. Their conventional methods for seeking marriage accentuate Elizabeth's dissimilar approach. Elizabeth's feminist views boldly challenge societal rules and reinforce her independence. Elizabeth proves her feminism is effective in impacting gender inequality in her society. When Elizabeth alters Mr. Darcy's character to make his moral standards match her own, in effect she is subverting the male-dominated society.

\subsection{Gender Views}

The first example is concerning the traditional education of women and the types of aspirations and achievements that are considered to be of value for women. Caroline represents the stereotypical Regency-era woman who has been well educated according to societal expectations, but she does not value intellectual achievements. In contrast, Elizabeth is deeply interested in intellectual pursuits yet she has not received a typical female education despite her family's means. Elizabeth and her sisters did not have a formal education, "steady and regular instruction" administered by a governess (Austen, 2003: 161). However, Elizabeth possesses a superior mind that makes her more striking to Mr. Darcy. Her lack of educational training is juxtaposed with Caroline's traditional female upbringing to accentuate foil contrast. Caroline is insecure because Mr. Darcy pays more attention to Elizabeth. Fawning over Mr. Darcy in a typical subservient female fashion, Caroline attempts to grab his attention. Although Caroline finds literature to be a dull diversion, she attempts to impress Mr. Darcy, an avid reader, by claiming she enjoys reading:

At length, quite exhausted by the attempt to be amused with her own book, which she had only chosen because it was the second volume of his, she gave a great yawn and said, 'How pleasant it is to spend an evening in this way! I declare after all there is no enjoyment like reading! How much sooner one tires of anything than of a book! -When I have a house of my own, I shall be miserable if I have not an excellent library.' (Austen, 2003: 54)

This female foil is representative of a traditional woman who aims to please the men, who are the target of her affections. Caroline says what she believes Mr. Darcy would like to hear and deceptively adopts the characteristics she believes Mr. Darcy would value in a woman. Her advances toward Mr. Darcy are motivated by a desire to gain his approval. From a feminist perspective, Caroline's actions are distinctive of the notion that a woman's worth is determined by the male-dominated society. She acquiesces to males who are of Mr. Darcy's demeanor and social status because she assumes this behavior is necessary to secure a husband.

Elizabeth's independent behavior sets her apart from the traditional women of Regency England. Lady Catherine de Bourgh once pointed out that Elizabeth never betrayed her own emotions or opinions to please anyone (Austen, 2003: 162). Elizabeth playfully claims to Caroline that "Mr. Darcy is not to be laughed at" due to his higher social standing (Austen, 2003: 56). When Mr. Darcy says Elizabeth's objective is to ridicule everyone, she replies, "I hope I never ridicule what is wise and good. Follies and nonsense, whims and inconsistencies, do divert me, I own, and I laugh at them whenever I can. But these, I suppose, are precisely what you are without" (Austen, 2003: 56). Elizabeth is aware of Mr. Darcy's higher station and prideful nature, yet she still boldly crosses social boundaries to articulate her opinions and ridicule Mr. Darcy and others. This is in a sharp contrast to Caroline's attention-seeking practice of ingratiating herself to a man to whom she is attracted. Elizabeth puts value on maintaining her own opinion and expressing it truthfully, while Caroline adapts her behavior to conform to whatever she deems will attract Mr. Darcy's attention. Adjusting her own opinions to mirror those of Mr. Darcy, Caroline becomes "his faithful assistant" (Austen, 2003: 39). Caroline fails in her incessant attempts to charm Mr. Darcy, while in contrast Elizabeth's persistent desire to state her mind instead draws Mr. Darcy's attention.

Elizabeth's assertion of her own opinion without regard for social dictates is a quality that intrigues Mr. Darcy. His reaction to Elizabeth's refusal to dance at Netherfield is a prime example of how her innate wit entrances him. Mr. Darcy asks Elizabeth to dance, however she only replies after he requests her hand a second time:

Oh...I heard you before, but I could not immediately determine what to say in reply. You wanted me, I know, to say 'Yes,' that you might have the pleasure of despising my taste; but I always delight in overthrowing those kind of schemes, and cheating a person of their premeditated contempt. I have, therefore, made up my mind to tell you, that I do not want to dance a reel at all—and now despise me if you dare. (Austen, 2003: 50)

Mr. Darcy's response to Elizabeth's rejection was startling. He made no objection, only replying that he would not despise her. Her refusal to dance with a male of higher class shows her independence, illustrating that women can state their own minds. Her departure from the conventions of social behavior, not an adherence to the stereotypical ideals, is what draws Mr. Darcy to her instead of Caroline. Caroline seeks the attention of Mr. Darcy because he is an affluent member of society. Elizabeth, however, gives no thought of gaining financial security through marriage, reinforcing her feminist stance in contrast to Caroline. 
The interactions among Elizabeth, Caroline and Mr. Darcy further highlight the contrast between the two women. For instance, when Caroline and Mr. Darcy question the assumption that all young women are accomplished, Elizabeth and Caroline each take opposing views. Mr. Darcy claims that most women do not deserve to be considered accomplished, and he himself "cannot boast of knowing more than half-a-dozen, in the whole range of [his] acquaintance, that are really accomplished." To which Caroline replied, "Nor I, I am sure... A woman must have a thorough knowledge of music, singing, drawing, dancing, and the modern languages, to deserve the word; and besides all this, she must possess a certain something in her air and manner of walking, the tone of her voice, her address and expressions, or the word will be but half-deserved" (Austen, 2003: 39). Mr. Darcy adds that in addition to all of this, in order to be accomplished, a woman must be well-read (Austen, 2003: 39). Caroline, seeking to please Mr. Darcy, affirms his opinion by listing the many requirements for a woman to be considered accomplished by her, and what she believes to be, Mr. Darcy's standards. In regards to his view on accomplished women, Elizabeth points out his high expectations are overinflated. She claims she is surprised Mr. Darcy even knows six accomplished women rather than none at all as she herself has never seen a woman who possesses these qualities "united" (Austen, 2003: 39). Elizabeth's feminist view on female achievement reflects the understanding that a woman's sense of accomplishment should not rest on the standards determined by Caroline and Mr. Darcy. Education for women at the time was dependent upon social class and wealth, and thus an unfair standard by which to judge all women. Elizabeth expresses her opposition to Mr. Darcy's standards for women by mocking him, expressing her feminist attitude.

The differences between Elizabeth and Caroline emphasize Elizabeth's feminist perspective. Caroline's fixation on gaining Mr. Darcy's attention by tempering her own opinions is a principle portrayal of the assumption that a woman's primary goal is obtaining an affluent husband. Caroline did not value a traditional academic education, illustrating a stereotypical perception of the time. Women were expected to excel in the fine arts, an option available only to women of a higher social standing, in order to find a "single man in possession of a good fortune" (Austen, 2003: 1). Elizabeth's statement suggests that women should not be severely judged by the standard of education imposed by society. Instead of strictly adhering to the social norms regarding female achievement, Elizabeth believed that the criteria for women to be accomplished were unjust. Her willingness to ridicule men of a high social class, in this case Mr. Darcy, supports the claim that Elizabeth did not engage in a restrictive way of thinking. Her superior wit and her non-traditional values allowed her to bend social rules. The "mixture of sweetness and archness in her manner" made it so that she could not offend Mr. Darcy even when she challenged him (Austen, 203: 51). He "had never been so bewitched by any woman as he was by her" (Austen, 2003: 51). He was attracted to Elizabeth's bold demeanor, unconventionality, and exceptional intelligence. Her disposition had a profound and unexpected influence on Mr. Darcy's own moral character.

\subsection{Assertiveness}

The second example accentuates Elizabeth's distinct feminist nature in comparison to her sister Jane. Representing a typical Regency-era woman, Jane's qualities differ from the previous example of Caroline. Jane is the quintessential ideal woman, beautiful, well mannered, and agreeable. At the time, it was a common practice for women to conceal their emotions from men (Gregory in Austen, 2003: 419). Jane's beauty and sweetness make her attractive to Mr. Bingley but her emotionally reserved nature as dictated by social norms failed to convince Mr. Bingley of her love. Innocently acquiescing to the rules of "guarded" female behavior, Jane had hoped to attract Mr. Bingley (Austen, 2003: 22). Ironically, Jane's cautious display of emotions as a way to please Mr. Bingley nearly caused her to lose his affection.

Jane passively displays her interest, leaving the rest of romance to the man. Following the quiet female archetype indicates a lack of strong personality, thus other characters are unable to discern her true feelings (Austen, 2003: 22). Mr. Darcy claims he believed Jane had no feelings for Mr. Bingley. In his letter to Elizabeth after she rejected his marriage proposal, he wrote:

Her [Jane's] look and manners were open, cheerful and engaging as ever, but without any symptom of peculiar regard, and I remained convinced from the evening's scrutiny, that though she received his [Mr. Bingley's] attentions with pleasure, she did not invite them by any participation of sentiment. (Austen, 2003: 192)

Charlotte's advice, even though it advocated scheming (Austen, 2003: 23), was correct in Jane's case. Her lack of strong feelings, and more importantly her kindness to all without reserve, was the primary cause of her sorrow.

Jane's naivety in adhering to the belief that women should appear cautious is sharply contrasted with Elizabeth's outspoken confidence. When Jane and Mr. Bingley met and danced at the Meryton ball, Jane's silent contentment is emphasized alongside her mother's excitement (Austen, 2003). Jane's reserved behavior is constrained by what she believes is required of her according to society's image of the ideal woman. The exposition of strong emotion was not considered to be proper behavior for women. In this regard, Jane typified a traditional woman, hiding her true emotions in order to secure a husband. Through her compliance with expected female behavior, Jane confirms her conventionality in the belief that women must modify themselves for men. Unlike Elizabeth, Jane did not permit herself to reveal her feelings to Mr. Bingley or others in his presence.

The conversation between Jane and Elizabeth about Mr. Bingley after the Meryton ball highlights their distinct personalities. Elizabeth is courageous, speaking her thoughts as they come to her, while Jane is passive and "cautious" in expressing her true feelings (Austen, 2003: 16). Elizabeth's candid expression shocked Jane, casting further contrast 
between the women. Jane, though honest, is not courageous. She is not as willing as Elizabeth to express or even hold strong opinions. Jane was astonished by Elizabeth's frank comment that Jane, who could not "be hasty in censuring anyone... may have liked a stupider person" than Mr. Bingley (Austen, 2003: 16). Jane meticulously observed what she perceived to be the proper actions of a woman pursuing marriage by passively displaying her thoughts and sentiments. In contrast, Elizabeth's bold and assertive demeanor is representative of feminist qualities not found within a stereotypical Regency-era woman.

The reactions of Jane and Elizabeth to Mr. Bingley leaving Netherfield illustrate their distinct differences. Caroline's letter reveals that the Bingley family had returned to London for the winter, and that Mr. Bingley was "partial" to Mr. Darcy's sister Georgiana (Austen, 2003: 131). When Jane reveals to Elizabeth the contents of the letter, Elizabeth insists that Mr. Bingley's sisters and Mr. Darcy have ill intent. Elizabeth openly accuses them of influencing Mr. Bingley to leave Netherfield in order to disrupt his romantic feelings for Jane, who could not imagine Mr. Bingley's sisters, Caroline or Mrs. Hurst intentionally impeding their romance. "If it is designedly done, they cannot be justified; but I have no idea of there being so much design in the world as some persons imagine" (Austen, 2003: 134). Jane was convinced that Mr. Bingley admired her. However, she mistakenly assumed Mr. Bingley's feelings were deeper than they truly were. Jane did not believe others would wish her ill if they knew her true feelings toward Mr. Bingley, assuring Elizabeth that the Bingley sisters only acted in the interest of his happiness. Elizabeth criticizes Jane's concern to please everyone, ridiculing her for potentially sacrificing her own happiness in order to please Mr. Bingley's sisters. "If, upon mature deliberation, you find that the misery of disobliging his two sisters is more than equivalent of the happiness of being his wife, I advise you by all means to refuse him" (Austen qtd. in Cook, 2005: 26). Asserting her independence from the expected female behavior in her society, Elizabeth rejects Jane's display of conventional values, urging Jane to assert her independence from the passivity that was expected. The attempt to influence her sister and others supports the notion that Elizabeth held a non-traditional feminist perspective.

Jane, in comparison to other women in the novel, was of a purer nature. According to Elizabeth, she is "a great deal too apt... to like people in general" (Austen, 2003: 16). Jane's strict adherence to social norms is the reason for her overly kind deportment. She was determined to please everyone by adopting a composed demeanor. Caroline was also refined and proper, yet in a contradictory manner. Unlike Jane's quiet reservation, Caroline actively draws attention to herself and resorts to deception in order to beguile her love interest. Jane and Caroline take different approaches when presenting themselves to men, although ultimately the underlying goal is the same. Both woman submit to societal expectations and deny their true thoughts for the sake of pleasing men, an approach Elizabeth denounced.

Jane's lack of character makes Elizabeth's liberal attitude more salient. Elizabeth's refusal of Mr. Darcy's first marriage proposal displays her daring attitude, openly revealing hostile feelings toward Mr. Darcy for impeding Jane and Mr. Bingley's happy marriage. Unlike Jane's relationship with Mr. Bingley, Elizabeth would never hide her emotions from Mr. Darcy. Elizabeth rejected Mr. Darcy's marriage proposal primarily due to his prejudiced feelings towards the Bennet family's lower social status and inferior connections. Mr. Darcy's proud self-image and stubborn views on society led him to obstruct Mr. Bingley and Jane's romance and also underestimate Elizabeth. His surprised reaction to Elizabeth's rejection is evidence of his arrogance. No woman had ever spoken to him with such frankness. Elizabeth's atypical character had a profound impact on Mr. Darcy.

Elizabeth and Jane greatly differed on their views of how a woman should behave. Jane believed that passive behavior was appropriate for attracting a husband. However, in practice, she was unable to show partiality in regards to Mr. Bingley. Elizabeth could not comprehend how other women could accept that falsely displaying sentiments was appropriate. She strongly believed that women should not be passive, as evidenced through her forthright criticism of Jane's inaction. Elizabeth refused to submit to the dictates of society that required women to be subservient to the wishes of men and those of a higher social status.

\subsection{Independence}

The third example of character contrast between Elizabeth and traditional women is that of Charlotte Lucas, Elizabeth's good friend. Little scholarly work has been done on the analysis of Charlotte's character. She may not be as simpleminded as she initially appears. Both Elizabeth and Charlotte entrust their true opinions with each other. Charlotte, desperate to find a husband, seeks an opportunity to charm Mr. Collins immediately after Elizabeth turns down his marriage proposal. To Elizabeth's disappointment, Charlotte pretends to enjoy Mr. Collins' stories in order to have "him in good humour" (Austen, 2003: 119-120). Although she did not think highly of marriage, Charlotte believed "it was the only honourable provision for well-educated women of small fortune" (Austen, 2003: 120). Charlotte sacrifices her own opinions to conform to the social dictate that a woman must marry. Her reflections on the engagement to Mr. Collins illustrate how she compromises her principles for the sake of her future:

The stupidity with which he was favored by nature, must guard his courtship from any charm that could make a woman wish for its continuance; and Miss Lucas, who accepted him solely from the pure and disinterested desire of an establishment, cared not how soon that establishment were gained... Mr. Collins, to be sure, was neither sensible nor agreeable; his society was irksome, and his attachment to her must be imaginary. But still he would be her husband... This preservative she had now obtained; and at the age of twenty-seven, without having ever been handsome, she felt all the good luck of it. (Austen, 2003: 120)

Charlotte labors to convince herself that the proper course of action is to find a husband who could provide her a 
comfortable life. Charlotte was eager to enter into marriage despite the likeability of her potential husband. Encouraging Mr. Collins is Charlotte's way of obtaining financial security. She knows that Mr. Collins would keep her wellestablished in the future, and thus exaggerates her feelings to assure him of her interest. There is a discrepancy between Charlotte's and Elizabeth's notions of the importance of marriage. Charlotte is willing to sacrifice her true opinions to ensure she is financially secure, a choice Elizabeth cannot accept. Although Charlotte did allude to her plans early in the novel, Elizabeth believes Charlotte would never give up her independence for a husband (Austen, 2003: 24). After Charlotte announces her decision to marry Mr. Collins, Elizabeth acknowledges a rift in their friendship, claiming "she felt persuaded that no real confidence could ever subsist between them again" (Austen, 2003: 125). Instead of being happy for her friend, Elizabeth reacted with astonishment and dismay (Austen, 2003: 122-123). Elizabeth could not envision abandoning the possibility of romance to ensure that she lived a comfortable life, further evidence of her determined independence and manifest feminism.

The relationship between Elizabeth and Charlotte portrays the conflict between non-traditional views and the typical female fixation on marriage. Elizabeth harshly judged her friend's decision to enter into marriage with Mr. Collins, deeming it an "unsuitable" match (Austen, 2003: 123). Although Elizabeth is aware of Charlotte's desire to marry Mr. Collins for economic reasons, she could not believe Charlotte would forfeit her happiness for worldly materials. The two are close companions, yet they have opposing outlooks on marriage. Elizabeth is certain Charlotte will not be able to share her opinions openly with Mr. Collins because their worldviews are significantly disparate. Charlotte is openminded and sensible like Elizabeth, while Mr. Collins is a pompous man with a "narrow-minded" view of the world (Austen, 2003: 133).

Elizabeth's self-determination is distinguished from Charlotte's compliance with traditional views on marriage. Elizabeth is nearly unmoved by economic considerations, a trait made evident in her rejection of both Mr. Collins' marriage proposal and Mr. Darcy's first marriage proposal. While Charlotte altered her own ideals and sacrificed her happiness for marriage and material goods, Elizabeth was successful in altering Mr. Darcy's moral character to match her own worldview for marriage. Mr. Darcy was first opposed to any romantic feelings towards Elizabeth due to her inferior connections. In the beginning, he struggled against his feelings for her "in vain" (Austen, 2003: 185). After much reflection, his initial opinion that he could not consider Elizabeth his equal gradually faded. He admitted he was attracted to Elizabeth for her genuine personality, as she gives her true opinions of society. Elizabeth challenged Mr. Darcy with her willfulness, especially her refusal of his first marriage proposal. Her independence draws his interest, and in the process influences his nature which had initially pitted him against her. Elizabeth's critical view of society reinforced through her unconventional exhibition strongly impacts Mr. Darcy's moral character. Through this transformation, Mr. Darcy is able to redeem himself in Elizabeth's eyes.

Elizabeth's refusal of Mr. Collins' marriage proposal is another instance of her unconventional ideals. She refused a respectable man meant to inherit her father's wealth. Elizabeth chose autonomy over financial security, showing her lack of concern with the conventional goals of women in Regency England. In refusing the marriage proposal, she denied her mother's wish to see one of her daughters wed Mr. Collins to save the family's fortune. Elizabeth believes that Mr. Collins, a conceited, foolish man, full of self-importance, is a poor choice for husband, made clear in her resolute refusal of his proposal (Austen, 2003). Despite the societal reproof she receives, Elizabeth is prideful in her composure. She insists that any man worthy of her hand should demonstrate a moral stance agreeable to her own. Many women did not consider what constituted a good marriage at that time, but rather focused on the material benefits. The rejection of two eligible bachelors is further proof of her feminist views on gender norms. Elizabeth's fight against the traditional society where women were deemed subservient provides evidence of her feminist struggle.

Charlotte, similar to Caroline, believes women must scheme to attract attention from men, however, her approach is much more subtle. Rather than deploy deception, Charlotte sacrifices her own good judgment. She explains to Elizabeth that women must carefully exhibit their emotions, even if they are not naturally in love. "If a woman conceals her affection with the same skill from the object of it, she may lose the opportunity of fixing him" (Austen, 2003: 22). The attention she gives him wins his affection, although she fails to secure her true happiness.

Charlotte's stereotypical notion of how women must act in order to find a husband is what separates her from Elizabeth. Charlotte schemes to charm Mr. Collins because he is "in want of a wife" (Austen, 2003: 1). She pursues him for his "character, connections, and situation in life" (Austen, 2003: 123). Charlotte's suggestion for Jane's interaction with Mr. Bingley is a foreshadowing of her own future relations with Mr. Collins. The overstatement of Charlotte's interest in Mr. Collins is used to gain his admiration, and secure her engagement. She claimed that happiness could not be guaranteed in a marriage, and that it was best "to know as little as possible of the defects" of a significant other (Austen, 2003: 23). Elizabeth opposed Charlotte's scheming, believing Charlotte was only in pursuit of a "rich husband" (Austen, 2003: 23). Elizabeth did not accept the view that she should aim to please men for the purpose of marriage. Instead, she was determined to find a husband who considered her an equal.

Charlotte made a practical decision to seek a marriage with a clergyman who could provide her a comfortable life. However, this decision was a rationalization that compromised her values of autonomy. Elizabeth, in contrast, cannot justify conceding her principles for the sake of marriage. She rejected proposals from two eligible bachelors that most traditional women would have happily accepted. Her independence is asserted in her refusing future economic security. Elizabeth opposes the conventional views of society that women must rely on men to secure their futures. For this reason, she cannot envision herself marrying Mr. Collins or Mr. Darcy. When Elizabeth refuses Mr. Collins' hand in marriage, she claims that he would never make her happy, and that she in turn could never please him (Austen, 2003: 
105). Later, she accepts Mr. Darcy's second marriage proposal, but only because he has changed his moral perceptions of society to match her worldview. Elizabeth believes that Mr. Darcy has been influenced by her own moral standards and societal expectations. Mr. Darcy's generosity during her family's scandal suggested to Elizabeth that he had abandoned his prejudiced views against her family. Elizabeth's ability to alter Mr. Darcy's moral character, in contrast to the other three foil examples, renders her the novel's feminist heroine.

\subsection{Discussion}

The foil contrasts between Elizabeth and the other female characters offer a distinctive approach to examining Elizabeth's feminist character, as evidenced in the above analysis. The juxtaposition of Caroline and Elizabeth accentuates Elizabeth's exceptional views on gender inequality in light of women's education, revealing her opinions on a prominent issue of her time. In comparison to Jane, Elizabeth's genuine bold nature is highlighted to illustrate her resolute assertiveness which attracts Mr. Darcy. In contrast to Charlotte, Elizabeth will not bend to the expectations of women in society to forfeit her autonomy for a profitable marriage, affirming her will over social dictates. Elizabeth's success in securing a marriage is in stark contrast to the failure of the more conventional endeavors from Caroline, Jane and Charlotte. Her independent thinking successfully wins Mr. Darcy's affections and profoundly impacts his moral character. Elizabeth's feminism in respect to the thematic contrasts of her character influences Mr. Darcy to desire her hand in marriage, proving the purpose of her feminist nature to alter Mr. Darcy's proud worldviews intended by Austen.

\section{Conclusion}

Elizabeth's feminist qualities are revealed when contrasted against the female foils in Pride and Prejudice. Austen's skillful writing utilizes these character foils to provide a contrast with her heroine Elizabeth and assert her feminist approach, and this research offers a method to revealing Austen's rhetoric. The traditional Regency-era woman is typified through Caroline, Jane and Charlotte. They adhere to the societal norms, modifying themselves in order to secure a husband. Elizabeth demonstrates how women are able to assert independence and still attract a desirable husband. She exercises her feminist power by altering Mr. Darcy's proud worldview. I argue that foil contrasts are essential to highlighting the strengths of Elizabeth's feminism, revealing a more nuanced understanding of her feminist nature. Comparing Elizabeth's qualities with Caroline, Jane, and Charlotte makes the assessment of the heroine's feminist character complete. I have shown the importance of foil contrast for appreciating Elizabeth's feminism; however more research is necessary to address the complexity of her character. Future research should elaborate on the more fundamental aspects of her character, such as her virtue, rhetorical nature, and innovative wit.

\section{References}

Austen, J. (2003). Pride and prejudice. London: Penguin Books. (Original work published 1813)

Bochman, Svetlana. (2005). Less than ideal husbands and wives: satiric and serious marriage themes in the works of Jane Austen and Oscar Wilde. (Doctoral dissertation). City University of New York, United States of America.

Brown, L.W. (1969). The comic conclusion in Jane Austen's novels. PMLA 84(6), 1582-1587.

- - - (1978). Jane Austen and the feminist tradition. Nineteenth-Century Fiction 28(3): 321-338.

Cook, J. (2005). A pragmatic analysis of irony. Language \& Information Society 6, 18-35.

Donovan, J. (1991). Women and the rise of the novel: A Feminist-Marxist theory. Signs 16(1), 441-462.

Duckworth, A.M. (1991). Jane Austen and the construction of a progressive author. College English 53(1), 77-90.

Hall, L.A. (2009). Grounding the figure of the heroine: the "other women" in Jane Austen's novels. (Doctoral dissertation). Claremont Graduate University, United States of America.

Hennessy, R. and Ingraham, C. (Eds.). (1997). Materialist feminism: A reader in class, difference, and women's lives. New York and London: Routledge.

Johnson, C.L. (1989). A 'sweet face as white as death': Jane Austen and the politics of female sensibility. A Forum on Fiction 22(2), 159-174.

Monteiro, B. (2008). The pleasures of comic mischief in Jane Austen's novels. (Doctoral dissertation). Boston University, United States of America.

Newman, K. (1983). Can this marriage be saved: Jane Austen makes sense of an ending. ELH 50(4), 693-710.

Newton, J.L. (1978). "Pride and prejudice": Power, fantasy, and subversion in Jane Austen. Feminist Studies 4(1), 2742.

Sullivan, Z. T. (1991). Theory for the untheoretical: Rereading and reteaching Austen, Bronte, and Conrad. College English 53(5), 571-579.

Toolan, M.J. (1988). Narrative: A critical linguistic introduction. Great Britain: Routledge.

\footnotetext{
${ }^{\mathrm{i}}$ Pride and Prejudice was originally published in London by T. Egerton in 1813. This study uses a reprinted edition from Penguin Classics based upon the first edition (Austen, 2003: xii).
} 